\title{
Education and Tiered Training of Early Childhood Educators : The Application of Andragogy Principals
}

\author{
Anne Rahaju \\ Department of NonFormal Education \\ Universitas Pendidikan Indonesia \\ Jl. Dr. Setiabudhi 229 Bandung 40154, Indonesia \\ anne.adinda@gmail.com
}

\begin{abstract}
Education and tiered training of early childhood educators is important because it aims to increase competence of an educator to become a professional educator. This paper address the application of andragogy principals in the education and tiered training for early childhood educators. It will systematically, factually, and accurately describe the character of education and tiered training of early childhood educators participant. The use of andragogy principals in this context is important because adults commonly have assumption, implications, and characteristics as an adult in executing teaching and learning activities
\end{abstract}

Keywords-Competence, Education, and tiered training, Adult Education

\section{INTRODUCTION}

Educator is one who has a major role and becomes a knowledge transfer for learners. It is generally accepted that the teacher is the most important factor affecting the quality of the student-school learning ${ }^{\left[{ }^{i}\right]}$ and it appears, therefore, appropriate to consider that teacher educators have an important influence on the quality of student-teacher learning. Increasingly recognized the importance of educators in scientific discussions, as reflected in the special issues of the European Journal of Teacher Education (vol. 31 [2]) and Professional Development in Education (vol. 36 [1/2]). ${ }^{[i]}$

Educators are professionals must have the competence, it can be seen ${ }^{\left[{ }^{i i i}\right]}$ that: Teachers are required to have academic qualifications, competence, teaching certificate, healthy physically and spiritually, as well as having the ability to realize the goal of education national. According to the communication of the European Commission 'Early Childhood Education and Care (ECEC): Providing all our children with the best start for the world of tomorrow' (2011) and based on the Mulai kuat III Report (OECD 2012), educated trained professional are key factors in provide high-quality ECEC with cognitive and social outcomes are most favorable for children. The key to the development of effective professional is to identify the right strategy to help practitioners stay updated on the method of pedagogical and subject knowledge curriculum while ensuring that the staff needs to fulfil ${ }^{[\mathrm{iv}]}$

The existence of educators of early childhood in the city of Bandung is the educators of non-formal early childhood must have competence as an educator who has sought to improve professionalism by implementing Educating training tiered (theory and independent tasks) performed by The set of early childhood educators (Himpaudi) as facilitators with funding from the Bandung Department of Education, in the hope of improving the professionalism of the educators. That "the development of education and training of quality educators should be taken as one of the major strategies for the cause of education". ${ }^{[\mathrm{V}]}$

Thus the importance of an educator to be able to follow the Basic Training to improve knowledge of the theory and practice so that no malpractice to learners and educators can make it know the extent of their abilities and how professionalism them as educators.

Education and training tiered of early childhood educators should be strengthened. Because it is designed to provide primary and secondary educators that are qualified, governments at all levels should increase investment in this area to offer more training and encourage outstanding high school graduates to take the exam to enter teacher education institutions. ${ }^{[\mathrm{vi}]}$

Broadly speaking, education and training in the quotation of this page were exported from Essay ${ }^{\text {[vii] }}$, can be defined as the acquisition of knowledge, skills, and attitudes that enable man to achieve individual goals and the organization today and in future ${ }^{\left[\text {viii }_{]}\right.}$

Nasution (2000: 71): " Education is a process, techniques and methods of teaching and learning with the intention of transferring knowledge from one person to another in accordance with the standards that have been set previously. 'Pont (1991: 46):' 'The training is to develop people as individuals and encouraging them to become more confident and capable in his life and his work. ". $\left.{ }^{[\mathrm{ix}}\right]$

According to Ahwood and Dimmoel perspective (1999: 32) were in the executive ${ }^{[\mathrm{X}]}$ : " more theoretical education in general knowledge, social and oriented to the needs of individuals, while training is a process of developing employee skills to do the job ongoing and jobs in the future."

\section{DISCUSSION}

The implications of the respective assumptions of adult education are the education and training tiered activities as follows: ${ }^{[\mathrm{xi}]}$ 


\section{A. Implications of assumptions about the concept of self}

- Climate study, to be created in accordance with the circumstances of adults: room, equipment, and cooperation of mutual respect.

- Participants included in diagnosing learning needs.

- Participants involved in the planning process of learning.

- Evaluation of learning in the process of learning andragogy to the way it stresses self-evaluation.

\section{B. The implication of assumptions about the experience}

- The learning process is emphasized to the techniques that are tapped into the experience, such as discussions, case method, simulations, practical exercises, project methods, demonstration, guidance, and seminars.

- The emphasis in the learning process in a practical application.

- The emphasis in the learning process is learning from experience.

\section{The implications of the assumptions about the readiness to} learn

- The sequence of the curriculum in adult learning is based on development tasks and is not listed in order of logical subjects or based on institutional needs.

- Their concept of developmental tasks in adults will provide guidance in the study group.

\section{The impact of assumptions about the orientation toward learning}

- The educators of adults are not the role of a teacher who teaches certain subjects, but he acted as aid to those who learn.

- The curriculum in education for adults is not oriented towards certain subjects but oriented to the problem.

Therefore adult learning problem-oriented learning experience is designed based on similarly to the problem or concern that is on their minds.

Teacher professionalism has been regarded as important by both successive governments in the UK and as a result of professional standards for educators have been introduced by Remolded. This paper seeks to examine the nature of teacher professionalism and in particular, consider the extent to which professionalism can be properly expressed through adherence to externally imposed standards. Further discussing the idea of professional characteristics or qualities and how expressions such as developing the professionalism that comes from within ourselves. ${ }^{\text {[xii] }}$

Stages of implementation of educating and training tiered program conducted by teachers and education personnel early childhood of Bandung in order to increase the professionalism consists of four stages, namely: ${ }^{\text {xiii] }}$
- Planning is the ability to plan a course of action that is precise and accurate.

- Organizing is the management functions associated with the distribution of tasks. Organizing facilitates managers in monitoring and determining those required to carry out the tasks that have divided.

- Actuating is a management function that relates to how to mobilize human resources in accordance with the division of tasks that have been performed on organizing function. Thus, the actuating principle had mobilized people to want to work with the full consciousness of itself or together to achieve the desired objectives effectively. In this case what is needed is leadership.

- Controlling is a regulatory process to measure or compare the plans that have been made with the implementation of which has been achieved. Given this oversight, it is expected there will be no errors or irregularities. Usually, the weakness in the function is the most frequent that create a management failure.

\section{CONCLUSION}

- The organizing of this training should be done by a professional / institution / organization / facilitator, it is related to many parties. Even a small mistake will have a very big impact. Therefore it is expected to be organized by those who are qualified in this field.

- Implications of the application of andragogy in education and training are as a facilitator who is very influential in the adult learning process. Facilitators into the classroom armed with some knowledge and experience. This knowledge and experience should exceed those of the participants. A facilitator with knowledge and experience is not enough to get people to behave in a classroom learning facilitators but the attitude is very important. A facilitator is not a "coercive" to the influence of the participants, but the effect arises because of their involvement in learning activities. To seek the change, the facilitator should be positive about the learners.

- Interest in the application of adult education and training tiered education of teachers and the training is to create an atmosphere that is meaningful, fun, creative, dynamic, and dialogue, so as to encourage the achievement of the purpose of education and training optimally with a conducive learning environment.

\section{REFERENCES}

[1] Barber and Mourshed 2007, Hattie, 2009

[2] Marco Snoek, Anja Swennen and Marcel van der Klink, 'The Quality of Teacher Educators in the European Policy Debate: Actions and Measures to Improve the Professionalism of Teacher Educators' Professional Development in Education, 37.5 (2011), 651-64 <http: // dx.doi.org/10.1080/19415257.2011.616095>

[3] Law Decree No. 14 of 2005 in Chapter IV of the Master.

[4] Tiina Peterson and others, 'Professionalism of Preschool Teachers in Estonia, Finland, Sweden and Hungary', European Early Childhood 
Journal, $24.1 \quad(2016), \quad 136-56$ Education Research Journal, 24.1
<http://dx.doi.org/10.1080/1350293X.2015.1120529>

[5] (Education NegaraKomisi, 1996a, p. 16) Daping Yang and Jianqiang $\mathrm{Wu}$, 'Some Issues in the Reform and Development of Teacher Education and Training in China ', Teacher Development, 3.2 (1999), 157-72 <http://dx.doi.org/10.1080/13664539900200078>.

[6] (CPC Central Committee and the state council, 1993, pp. 18-19) Daping WU YANG \& Jianqiang

[7] [http://karyatulisilmiah.com]

[8] Export date: Mon Jun 16 9:48:41 2016/+0000 GMT

[9] Bambrough, 1998: 1
[10] http://karyatulisilmiah.com.

[11] http://karyatulisilmiah.com

[12] taff.uny.ac.id/system/files/.../HANDOUT\%20ANDRAGOGI.do

[13] Janet Goepel, 'Upholding the Public Trust: An Examination of Teacher Professionalism and the Use of Teachers' Standards in England', Teacher Development, $16.4 \quad$ (2012), <http://dx.doi.org/10.1080/13664530.2012. 729 784>.

[14] Http://hakikatbisnis.blogspot.co.id/2015/06/pengertian-poac-dalamilmu-manajemen-lengkap.html 